\title{
Antibiotic resistance of lactic acid bacteria isolated from Chinese yogurts
}

\author{
N. Zhou, ${ }^{*}$ J. X. Zhang, ${ }^{*}$ M. T. Fan, ${ }^{*}$ J. Wang, ${ }^{*}$ G. Guo,† and X. Y. Wei ${ }^{* 1}$ \\ ${ }^{*}$ College of Food Science and Engineering, Northwest A\&F University, Shaanxi 712100, China \\ †Haikou Experimental Station/Institute of Banana and Plantain, Chinese Academy of Tropical Agriculture (CATAS), Haikou, Hainan 570102, China
}

\section{ABSTRACT}

The aim of this study was to evaluate the susceptibility of 43 strains of lactic acid bacteria, isolated from Chinese yogurts made in different geographical areas, to 11 antibiotics (ampicillin, penicillin G, roxithromycin, chloramphenicol, tetracycline, chlortetracycline, lincomycin, kanamycin, streptomycin, neomycin, and gentamycin). The 43 isolates (18 Lactobacillus bulgaricus and 25 Streptococcus thermophilus) were identified at species level and were typed by random amplified polymorphic DNA analysis. Thirty-five genotypically different strains were detected and their antimicrobial resistance to 11 antibiotics was determined using the agar dilution method. Widespread resistance to ampicillin, chloramphenicol, chlortetracycline, tetracyclines, lincomycin, streptomycin, neomycin, and gentamycin was found among the 35 strains tested. All of the Strep. thermophilus strains tested were susceptible to penicillin $\mathrm{G}$ and roxithromycin, whereas 23.5 and $64.7 \%$ of Lb. bulgaricus strains, respectively, were resistant. All of the Strep. thermophilus and Lb. bulgaricus strains were found to be resistant to kanamycin. The presence of the corresponding resistance genes in the resistant isolates was investigated through PCR, with the following genes detected: tet( $\mathrm{M})$ in $1 \mathrm{Lb}$. bulgaricus and 2 Strep. thermophilus isolates, ant(6) in $2 \mathrm{Lb}$. bulgaricus and 2 Strep. thermophilus isolates, and aph(3')-IIIa in $5 \mathrm{Lb}$. bulgaricus and 2 Strep. thermophilus isolates. The main threat associated with these bacteria is that they may transfer resistance genes to pathogenic bacteria, which has been a major cause of concern to human and animal health. To our knowledge, the $\operatorname{aph}\left(3^{\prime}\right)$-IIIa and ant(6) genes were found in Lb. bulgaricus and Strep. thermophilus for the first time. Further investigations are required to analyze whether the genes identified in Lb. bulgaricus and Strep. thermophilus isolates might be horizontally transferred to other species.

Key words: lactic acid bacteria, antibiotic resistance, yogurt

\footnotetext{
Received December 18, 2011.

Accepted May 22, 2012.

${ }^{1}$ Corresponding author: wheixinyuan@126.com
}

\section{INTRODUCTION}

Lactic acid bacteria (LAB) are common microorganisms in foods and also constitute the natural intestinal microbiota of humans and most animals. Lactic acid bacteria are involved in various kinds of fermentative processes, including lactic acid fermentation for yogurt production, in which Lactobacillus bulgaricus and Streptococcus thermophilus are commonly used (Adolfsson et al., 2004). During the fermentation, lactose is converted into lactic acid, which acts on milk protein to give yogurt its texture and its characteristic tang (Lourens-Hattingh and Viljoen, 2001).

The increased use of LAB in food production as probiotics over the last decades has raised safety issues, one of which is the nature of acquiring and distribution of antimicrobial resistance (Teuber et al., 1999; Ammor et al., 2007). Antimicrobial resistance is an increasing problem worldwide, with the effective treatment of bacterial infections being compromised. The extensive use of antibiotics in both human and animal treatment has created a selective pressure for acquisition of resistance phenotypes that can be transmitted via food. The evolution of antibiotic-resistant foodborne pathogens has been widely reported (Zhao et al., 2006; Rahimi et al., 2010; Gousia et al., 2011). Recently, several studies have investigated the role of commensal bacteria (such as LAB) as reservoirs of antibiotic resistance genes similar to those found among human pathogens (Salyers et al., 2004; Toomey et al., 2010). The main threat associated with these bacteria is that they could transfer resistance genes to pathogenic bacteria (Flórez et al., 2005).

The food chain is considered as one of the main routes of transmission of antibiotic-resistant bacteria between animal and human populations. In particular, fermented dairy products that are not heat treated before consumption provide a vehicle for antibiotic-resistant bacteria, with a direct link between the animal indigenous microflora and the human gastrointestinal tract (Mathur and Singh, 2005). The incidence of antibiotic-resistant Lactobacillus plantarum, Lactobacillus paracasei, Lactobacillus reuteri, and Lactobacillus acidophilus in food has been reported (Rojo-Bezares et al., 
2006; D'Aimmo et al., 2007; Liu et al., 2009). However, only limited information about the occurrence of different resistance genes among Lb. bulgaricus and Strep. thermophilus from yogurts is available. The aim of this work was to study the occurrence of antimicrobial resistance and presence of selected resistance genes among Lb. bulgaricus and Strep. thermophilus isolated from yogurts made in different places in China.

\section{MATERIALS AND METHODS}

\section{Isolation and Identification of LAB}

Forty-three strains of LAB, including 18 strains of $L b$. bulgaricus and 25 strains of Strep. thermophilus, were isolated from yogurts collected from dairy plants located in different places in China. Lactobacillus bulgaricus and Strep. thermophilus were used as starter cultures. Recovered strains derived from yogurts were isolated on de Man, Rogosa, and Sharpe (MRS) agar (Oxoid Ltd., Basingstoke, UK) supplemented with $0.75 \% \mathrm{CaCO}_{3}$. Isolates with dissolved calcium were initially identified by colonial appearance, Gram staining, cell morphology, catalase reaction, and yogurt coagulation test. The putative LAB identified were further confirmed by PCRbased $16 \mathrm{~S}$ rDNA sequencing, using a pair of universal primers 27f (5'-AGAGTTTGATCCTGGCTCAG- $\left.3^{\prime}\right)$ and 1495r (5'-CTACGGCTACCTTGTTACGA-3'; Yu et al., 2011).

\section{Strain Typing}

Genomic DNA was extracted from different isolates of overnight MRS broth cultures using the CTAB method described by Moore et al. (2004). Eight random primers (Table 1), P2, P15, P17, COC, Lp1, OPL-05, CRA23, and CRA25, were tested for their ability to discriminate between strains of $\mathrm{LAB}$ and for their reproducibility. Primer CRA23, which showed higher discriminatory ability, was selected for random ampli- fied polymorphic DNA (RAPD) analysis. Polymerase chain reaction was conducted in a total volume of 25 $\mu \mathrm{L}$, containing $10 \mathrm{mmol}$ of Tris- $\mathrm{HCl} / \mathrm{L}(\mathrm{pH} 8.3$ ), 50 mmol of KCl/L, $2.0 \mathrm{mmol}$ of $\mathrm{MgCl}_{2} / \mathrm{L}, 0.2 \mathrm{mmol} / \mathrm{L}$ of each deoxyribonucleotide triphosphate (dNTP), $2 \mu \mathrm{mol}$ of primer/L, 1.25 U of Taq polymerase and $100 \mathrm{ng}$ of extracted DNA. Amplification was carried out in a Peltier thermal cycler (PTC-200; MJ Research Inc., St. Bruno, QC, Canada) under the conditions listed in Table 1. The PCR products were separated by electrophoresis on a $1.5 \%$ (wt/vol) agarose gel in $0.5 \times$ Tris/borate/ EDTA (TBE) buffer. Random amplified polymorphic DNA profiles were obtained directly using a digital camera (Bio-Rad Laboratories Inc., Hercules, CA) and analyzed with the pattern analysis software NTSYS-pc version 2.1e (Exeter Software, Setauket, NY). Calculation of similarity of the PCR fingerprinting profiles was based on the Pearson product-moment correlation coefficient. A dendrogram was deduced from the matrix of similarities by the unweighted pair group method using arithmetic mean (UPGMA). Reproducibility was tested by repeating the PCR amplification at least 3 times under the same amplification conditions.

\section{Antibiotic Susceptibility Testing}

The phenotypic antimicrobial resistance of a strain to each antibiotic tested was determined as the MIC, defined as the lowest antibiotic concentration that will inhibit the visible growth of a microorganism after overnight incubation (Andrews, 2001). The MIC for 11 antibiotics (ampicillin, penicillin G, roxithromycin, chloramphenicol, chlortetracycline, tetracycline, lincomycin, kanamycin, streptomycin, neomycin, and gentamycin) was determined by the agar dilution method on MRS agar according to a modification of the Clinical and Laboratory Standards Institute (CLSI) standards (CLSI, 2009). The assay was performed in duplicate and repeated on 3 independent occasions. As no definitive breakpoint list has been established for lactic acid bac-

Table 1. Random primers and PCR conditions used in this study

\begin{tabular}{llll}
\hline Random primer & Sequence $\left(5^{\prime}-3^{\prime}\right)$ & $\begin{array}{c}\text { Annealing } \\
\text { temperature }\left({ }^{\circ} \mathrm{C}\right)\end{array}$ & Reference $^{1}$ \\
\hline P2 & GATCGGACGG & 36 & Samaržija et al. (2002) \\
P15 & CTGGGCACGA & 36 & Samaržija et al. (2002) \\
P17 & CAGACAAGCC & 35 & Samaržija et al. (2002) \\
Lp1 & ACGCGCCCT & 33 & Johansson et al. (1995) \\
COC & AGCAGCGTGG & 36 & Cocconcelli et al. (1995) \\
OPL-05 & ACGCAGGCA & 36 & Van Reenen and Dicks (1996) \\
CRA23 & GCGATCCCCA & 36 & Daud Khaled et al. (1997) \\
CRA25 & AACGCGCAAC & 36 & Daud Khaled et al. (1997) \\
\hline
\end{tabular}

${ }^{1}$ References for random primer sequence only. 
Table 2. Microbiological breakpoints for Lactobacillus bulgaricus and Streptococcus thermophilus used in food or as probiotics

\begin{tabular}{|c|c|c|c|c|}
\hline \multirow[b]{2}{*}{ Antibiotic } & \multirow[b]{2}{*}{ Species } & \multicolumn{3}{|c|}{ Proposed breakpoint, MIC $(\mu \mathrm{g} / \mathrm{mL})$} \\
\hline & & This paper & $\mathrm{EFSA}^{1}$ & Other articles \\
\hline \multirow[t]{2}{*}{ Ampicillin } & Lb. bulgaricus & 1 & 1 & $2,^{2} 8,{ }^{3} 4^{4}$ \\
\hline & Strep. thermophilus & 2 & 2 & \\
\hline \multirow[t]{2}{*}{ Penicillin G } & Lb. bulgaricus & 1 & & $4^{3,4}$ \\
\hline & Strep. thermophilus & 1 & & $4^{3}$ \\
\hline \multirow[t]{2}{*}{ Roxithromycin } & Lb. bulgaricus & 1 & & \\
\hline & Strep. thermophilus & 2 & & \\
\hline \multirow[t]{2}{*}{ Chloramphenicol } & Lb. bulgaricus & 4 & 4 & $16^{2,3,4}$ \\
\hline & Strep. thermophilus & 4 & 4 & $16^{2}$ \\
\hline \multirow[t]{2}{*}{ Chlortetracycline } & Lb. bulgaricus & 1 & & \\
\hline & Strep. thermophilus & 1 & & \\
\hline \multirow[t]{2}{*}{ Tetracycline } & Lb. bulgaricus & 4 & 4 & $16,^{2} 8,^{3} 4^{4}$ \\
\hline & Strep. thermophilus & 4 & 4 & $8^{2}$ \\
\hline \multirow[t]{2}{*}{ Lincomycin } & Lb. bulgaricus & 4 & & \\
\hline & Strep. thermophilus & 4 & & \\
\hline \multirow[t]{2}{*}{ Kanamycin } & Lb. bulgaricus & 16 & 16 & $32,{ }^{2}>256^{3}$ \\
\hline & Strep. thermophilus & 64 & 64 & \\
\hline \multirow[t]{2}{*}{ Streptomycin } & Lb. bulgaricus & 16 & 16 & $16,^{2,3}>256^{4}$ \\
\hline & Strep. thermophilus & 64 & 64 & $16^{3}$ \\
\hline \multirow[t]{2}{*}{ Neomycin } & Lb. bulgaricus & 32 & & $32^{1}$ \\
\hline & Strep. thermophilus & 32 & & \\
\hline \multirow[t]{2}{*}{ Gentamycin } & Lb. bulgaricus & 16 & 16 & $1{ }_{2}^{2} 16^{3}$ \\
\hline & Strep. thermophilus & 32 & 32 & $16^{3}$ \\
\hline
\end{tabular}

${ }^{1}$ Breakpoints defined by the European Food Safety Authority (EFSA, 2008) for Lb. bulgaricus and Strep. thermophilus.

${ }^{2}$ Breakpoints defined by the European Commission (EC, 2001) for Lactobacillus spp.

${ }^{3}$ Breakpoints suggested by Katla et al. (2001) for Lactobacillus spp. and Strep. thermophilus.

${ }^{4}$ Breakpoints suggested by Danielsen and Wind (2003) for Lactobacillus spp.

teria, susceptibility to the antibiotics was determined by comparing MIC values to the proposed breakpoints from previous studies. Some breakpoints that were not published anywhere before, such as breakpoints for roxithromycin and chlortetracycline, were defined according to the breakpoints for antibiotics in the same type, as presented in Table 2. Strains with MIC equal to or higher than the breakpoints are considered as resistant (EC, 2001).

\section{Genotypic Detection of Antimicrobial Resistance Genes}

Determination of the genetic background to phenotypic resistance was achieved by applying PCR with specific primers for known antibiotic resistance genes. Genes responsible for resistance to tetracycline $[$ tet $(\mathrm{K})$, tet $(\mathrm{L}), \operatorname{tet}(\mathrm{M}), \operatorname{tet}(\mathrm{O}), \operatorname{tet}(\mathrm{S})$, and $\operatorname{tet}(\mathrm{W})]$, streptomycin $[\operatorname{str}(\mathrm{A}), \operatorname{str}(\mathrm{B})$, and ant $(6)]$, chloramphenicol $[\operatorname{cat}(\mathrm{A})]$, gentamycin $\left[\operatorname{aac}\left(6^{\prime}\right)-\operatorname{aph}\left(2^{\prime \prime}\right)\right]$, and kanamycin $\left[\operatorname{aph}\left(3^{\prime}\right)\right.$ IIIa] were amplified by PCR using primers listed in Table 3, according to amplification conditions described by the references. Polymerase chain reaction products $(7 \mu \mathrm{L})$ were separated by $1.5 \%$ (wt/vol) agarose gel electrophoresis in $0.5 \times \mathrm{TBE}$ buffer and visualized by ethidium bromide $(10 \mathrm{mg} / \mathrm{mL})$ staining.

\section{RESULTS}

\section{Biodiversity of LAB Isolates}

A notable genotypic heterogeneity among the 43 LAB isolates was observed by RAPD fingerprinting (Figure 1). The majority of fingerprinting profiles represented unique genotypes with rather low correlation values (49\%), resulting in a high degree of biodiversity. The profiles of some isolates, however, were found to cluster together in the same branch of the dendrogram. Overall, a total of 35 genotypically different strains were detected at the level of reproducibility (92\% similarity; data not shown), and were then subjected to further analysis.

\section{Antibiotic Susceptibility Testing}

The agar dilution method was used to assess the susceptibility of the $35 \mathrm{LAB}$ strains isolated from yogurts to 11 antibiotics, ampicillin, penicillin G, roxithromy- 
Table 3. Primers for selected antibiotic resistance genes and PCR conditions used in this study

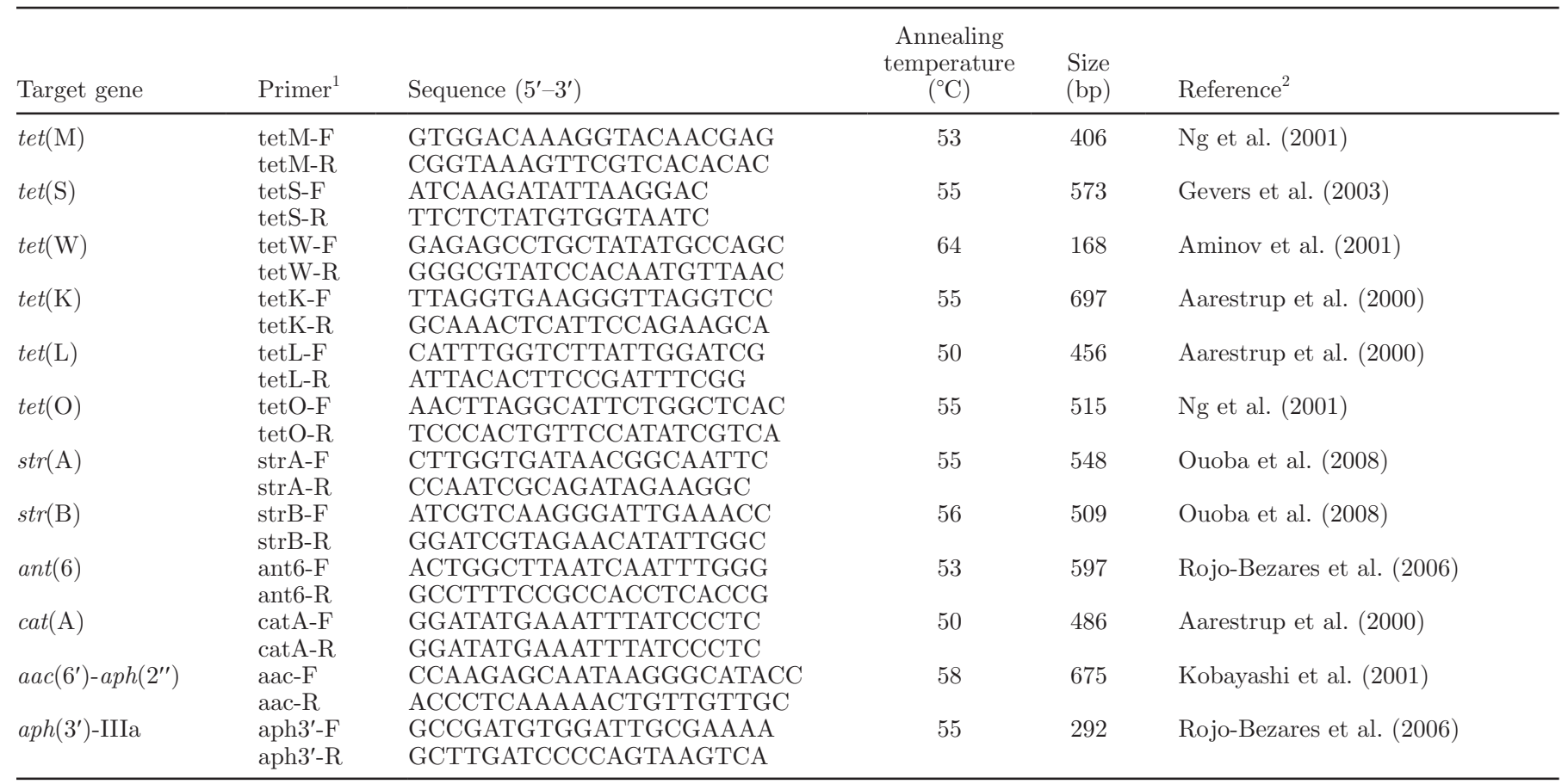

${ }^{1} \mathrm{~F}=$ forward; $\mathrm{R}=$ reverse.

${ }^{2}$ References for primer sequence and size only.

cin, chloramphenicol, chlortetracycline, tetracycline, lincomycin, kanamycin, streptomycin, neomycin, and gentamycin. The MIC distributions of the tested strains are presented in Table 4 . The strains were characterized as either resistant or sensitive to a specific antibiotic according to the proposed breakpoints listed in Table 2. Irrespective of the medium of isolation, all of the Strep. thermophilus isolates were found to be susceptible to penicillin $\mathrm{G}$ and roxithromycin, whereas 23.5 and $64.7 \%$ of $L b$. bulgaricus isolates, respectively, were resistant. Moderate levels of resistance to ampicillin and chlortetracycline were observed among $L b$. bulgaricus (29.4 and $47.1 \%$, respectively) and Strep. thermophilus (44.4 and $27.8 \%$, respectively). Resistance to tetracycline varied significantly between the 2 species, as $88.2 \%$ for $L b$. bulgaricus and $44.4 \%$ for Strep. thermophilus.

High-level resistance to chloramphenicol and lincomycin was observed for Lb. bulgaricus (88.2 and 94.1\%, respectively) and for Strep. thermophilus (88.9 and $88.9 \%$, respectively). Both Lb. bulgaricus and Strep. thermophilus strains tend to be strongly resistant to aminoglycosides (kanamycin, streptomycin, neomycin, and gentamycin). In fact, only $5.9 \%$ of Lb. bulgaricus isolates showed susceptibility to streptomycin, neomycin, or gentamycin and 33.3 and $11.1 \%$ of Strep. thermophilus isolates were susceptible to streptomycin and gentamycin, respectively.

\section{Resistance Phenotypes Analysis}

The isolates tested were found to exhibit combined resistance among the 11 antibiotics (ampicillin, penicillin $\mathrm{G}$, roxithromycin, chloramphenicol, chlortetracycline, tetracycline, lincomycin, kanamycin, streptomycin, neomycin, and gentamycin). Most isolates (91.4\%) showed resistance to 5 to 10 of the antibiotics, whereas certain isolates $(51.4 \%)$ were resistant to 8 or more antibiotics.

\section{Detection of Antibiotic Resistance Genes}

All of the antibiotic-resistant strains were tested for the presence of antibiotic resistance genes most frequently occurring in LAB by PCR amplification. Table 5 presents the tested strains in which antibiotic resistance genes have been detected, as well as the MIC of the antibiotics affected by the products of these resistance genes.

The tet $(\mathrm{M})$ gene was detected in $1(6.67 \%)$ of the 15 tetracycline-resistant $L b$. bulgaricus isolates and in 2 (25\%) of the 8 tetracycline-resistant Strep. thermophilus isolates. The incidence of ant(6) was $12.5 \%$ among the streptomycin-resistant $L b$. bulgaricus isolates, whereas the incidence was $16.7 \%$ among the streptomycinresistant Strep. thermophilus isolates. Five (29.4\%) of the 17 kanamycin-resistant Lb. bulgaricus isolates and 

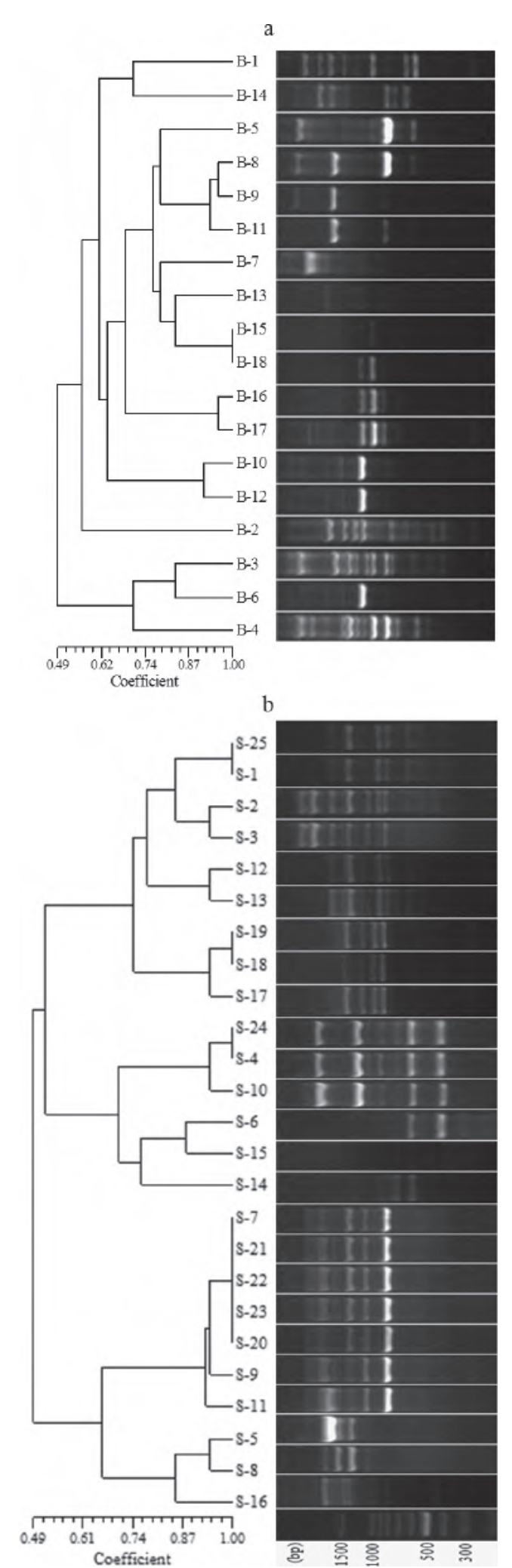

Figure 1. Unweighted pair group method using arithmetic mean (UPGMA)-based dendrogram from the random amplified polymorphic DNA (RAPD) profiles generated with primer CRA23 of 18 Lactobacillus bulgaricus (a) and 25 Streptococcus thermophilus (b) isolates collected from Chinese yogurts.
$2(11.1 \%)$ of the 18 kanamycin-resistant Strep. thermophilus isolates were found to contain the aph $\left(3^{\prime}\right)$-IIIa gene.

\section{DISCUSSION}

Dissemination of antibiotic resistance through the food chain is a serious public health issue, and resistance in fermented dairy products is a component of this paradigm. Lactobacillus bulgaricus as well as Strep. thermophilus, generally regarded as safe (GRAS), are the main starter cultures for the production of yogurts. Although their probiotic functions have rendered them common food additives (Irkin and Eren, 2008), recent reports have pointed out a possible pathogenic relevance of several LAB species, including $L b$. bulgaricus and Strep. thermophilus (D'Aimmo et al., 2007; Klare et al., 2007; Liu et al., 2009). Up to the present, only a few studies have focused on the identification of antibiotic resistance determinants in these species (Liu et al., 2009), although their widespread presence in fermented foods, as well as the strong selection of antibiotic resistance due to extensive use of antibiotics (Teuber, 2001; Wegener, 2003), make them potential vehicles for the spread of antibiotic resistance genes to human pathogens (Teuber and Perreten, 2000).

To study intraspecies diversity of $L b$. bulgaricus and Strep. Thermophilus isolated from yogurts, all 43 strains were subjected to RAPD analysis with primer CRA23. As a result, a total of 35 genotypically different strains were selected for further analysis. The reproducibility of the RAPD assay and running conditions estimated by analysis of repeated DNA extracts of several type strains was $92 \%$ (data not shown). Random amplified polymorphic DNA fingerprinting is one of the most commonly used typing techniques, and is widely used for typing dairy LAB (Andrighetto et al., 2002; de Candia et al., 2007). It has been widely reported as a rapid, sensitive, and inexpensive method for genetic typing of different strains of LAB, although the reproducibility and discriminatory power of the RAPD fingerprints is lower than that of pulsed-field gel electrophoresis (PFGE) and can be influenced by several factors, such as annealing temperature, DNA template purity and concentration, and primer combinations (Amor et al., 2007). However, high reproducibility and discriminatory power can be obtained with optimized protocols.

At present, widespread susceptibility toward the inhibitors of cell wall synthesis (such as penicillin and ampicillin) has been observed in many species of LAB from different sources, including cheese (Belletti et al., 2009), probiotics or fermented foods (Charteris et al., 1998), and human intestine (Delgado et al., 2005). Most of the Lb. bulgaricus isolates tested in the current study 
Table 4. Minimum inhibitory concentration distributions for 11 antibiotics of Lactobacillus bulgaricus and Streptococcus thermophilus isolates from yogurts in the Chinese market

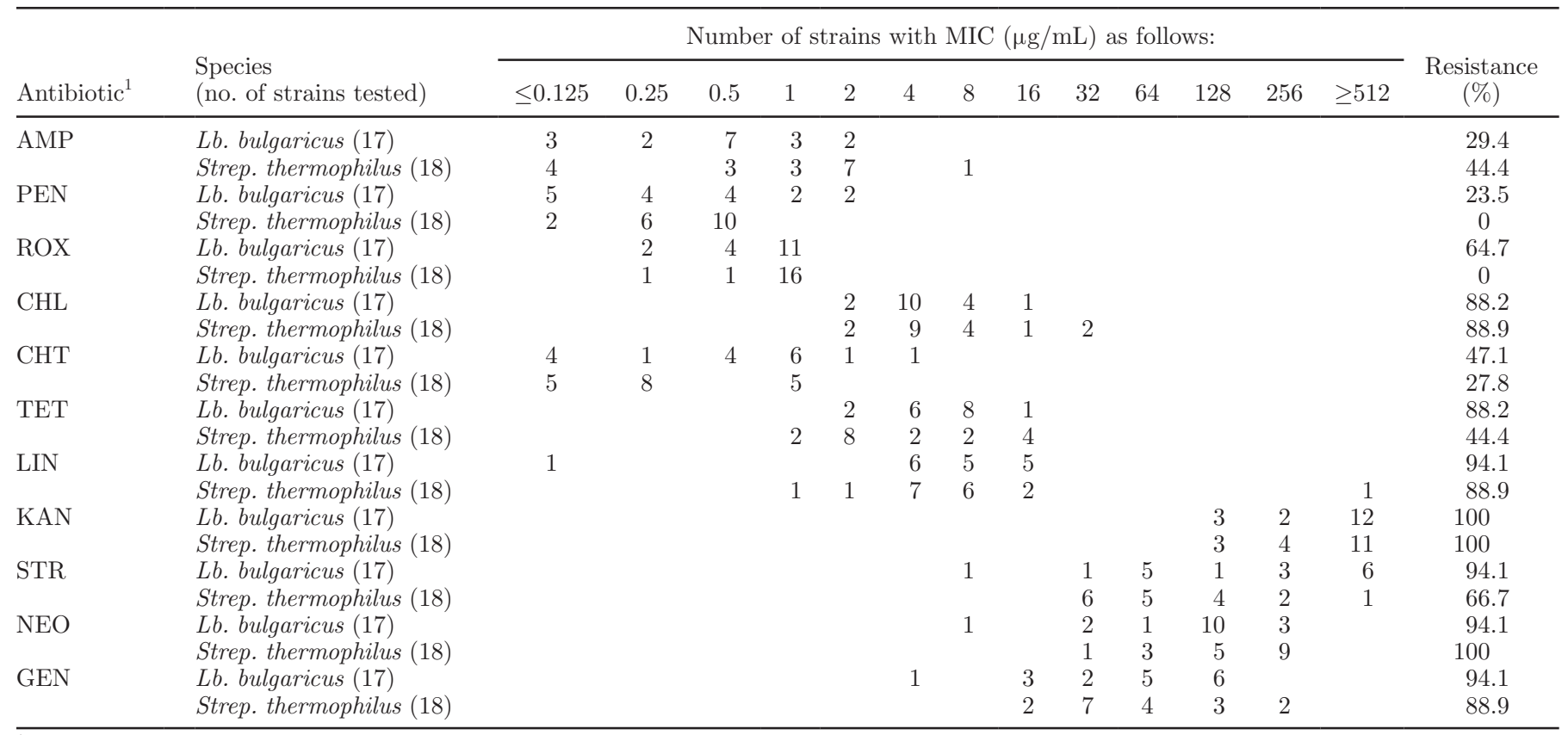

${ }^{1} \mathrm{AMP}=$ ampicillin; $\mathrm{PEN}=$ penicillin; $\mathrm{ROX}=$ roxithromycin CHL $=$ chloramphenicol; $\mathrm{CHT}=$ chlortetracycline; $\mathrm{TET}=$ tetracycline; $\mathrm{LIN}=$ lincomycin; KAN = kanamycin; STR = streptomycin; $\mathrm{NEO}=$ neomycin; GEN = gentamycin .

were found to be sensitive to penicillin and ampicillin. Resistance to roxithromycin and chlortetracycline, although seldom reported, was also found in the current study. Nawaz et al. (2011) found a high portion of the $L b$. bulgaricus strains susceptible to chloramphenicol, tetracycline, and lincomycin. This is in contrast to our observations that the Lb. bulgaricus strains had MIC quite a bit higher than the breakpoint values, and this difference may due to different media used in the MIC testing and also may because isolates tested are from different origins.
A high level of resistance to aminoglycosides was found in almost all of the investigated strains (Table 4). A tendency toward lower MIC was observed for gentamicin, in comparison with kanamycin, streptomycin, and neomycin. Unlike gentamicin, which showed a unimodal MIC distribution at the low-end concentration range, the other aminoglycoside antibiotics (streptomycin, kanamycin, and neomycin) displayed broad MIC distributions at the high-end concentration range. Generally, the reduced susceptibility of lactobacilli to aminoglycosides is thought to occur because of mem-

Table 5. Lactic acid bacteria strains in which antibiotic resistance genes and MIC of specific antibiotics have been detected

\begin{tabular}{|c|c|c|c|}
\hline Species & Strain & $\begin{array}{l}\text { Antibiotic } \\
\text { (MIC in } \mu \mathrm{g} / \mathrm{mL} \text { ) }\end{array}$ & $\begin{array}{l}\text { Resistance } \\
\text { gene detected }\end{array}$ \\
\hline \multirow[t]{8}{*}{ Lactobacillus bulgaricus } & B-4 & Tetracycline (16) & $\operatorname{tet}(\mathrm{M})$ \\
\hline & & Streptomycin (64) & $\operatorname{ant}(6)$ \\
\hline & B-9 & Streptomycin (512) & $\operatorname{ant}(6)$ \\
\hline & B-3 & Kanamycin (512) & $\operatorname{aph}\left(3^{\prime}\right)$-IIIa \\
\hline & B-10 & Kanamycin $(\geq 512)$ & $\operatorname{aph}\left(3^{\prime}\right)-$ IIIa \\
\hline & B-11 & Kanamycin (512) & $\operatorname{aph}\left(3^{\prime}\right)$-IIIa \\
\hline & B-15 & Kanamycin (512) & $\operatorname{aph}\left(3^{\prime}\right)$-IIIa \\
\hline & B-13 & Kanamycin (256) & $\operatorname{aph}\left(3^{\prime}\right)$-IIIa \\
\hline \multirow[t]{6}{*}{ Streptococcus thermophilus } & S-1 & Tetracycline (16) & $\operatorname{tet}(\mathrm{M})$ \\
\hline & $\mathrm{S}-3$ & Tetracycline (8) & $\operatorname{tet}(\mathrm{M})$ \\
\hline & $\mathrm{S}-4$ & Streptomycin (256) & $\operatorname{ant}(6)$ \\
\hline & $\mathrm{S}-10$ & Streptomycin $(256)$ & $\operatorname{ant}(6)$ \\
\hline & S-7 & Kanamycin (512) & $\operatorname{aph}\left(3^{\prime}\right)$-IIIa \\
\hline & S-18 & Kanamycin (512) & $\operatorname{aph}\left(3^{\prime}\right)$-IIIa \\
\hline
\end{tabular}


brane impermeability (Elkins and Mullis, 2004). Due to the better ability of gentamicin to cross the membrane, a tendency toward lower MIC for gentamicin is known (Danielsen and Wind, 2003; Egervärn et al., 2007). Additionally, interference by low test medium $\mathrm{pH}$ (MRS agar, $6.2 \pm 0.2$ ) with aminoglycosides (the optimum $\mathrm{pH}$ 7.8) might be attributed to reducing their antibacterial activity (Amsterdam, 2005).

An association between the occurrence of resistance to the different antimicrobial agents tested was found. Among Lb. bulgaricus isolates, the combined resistance to chloramphenicol, tetracycline, lincomycin, kanamycin, streptomycin, neomycin, and gentamycin was commonly found. However, Strep. thermophilus isolates were much more frequently observed with combined resistance to chloramphenicol, lincomycin, kanamycin, neomycin, and gentamycin, without tetracycline and streptomycin. The significant multidrug resistance reinforces the antimicrobial susceptibility testing in the safety assessment procedure of strains intended for probiotic or nutritional use.

Detection of antibiotic resistance genes showed that the tet(M) gene was detected in $1 \mathrm{Lb}$. bulgaricus strain and 2 Strep. thermophilus strains. The 3 tet $(\mathrm{M})$-possessing strains presented higher MIC values of tetracycline than other LAB strains tested in this study. The tet $(\mathrm{M})$ gene encodes a soluble protein to protect the ribosome from the effects of tetracycline, thus conferring tetracycline resistance. These 3 tet $(\mathrm{M})$-owning strains represent examples of acquired resistance in LAB.

The aph(3')-IIIa gene, exhibiting high-level resistance to kanamycin, was detected in $5 \mathrm{Lb}$. bulgaricus strains and 2 Strep. thermophilus strains in this study. The kanamycin MIC values for the 7 aph $\left(3^{\prime}\right)$-IIIa-containing strains were $256 \mu \mathrm{g} / \mathrm{mL}$ or $\geq 512 \mu \mathrm{g} / \mathrm{mL}$, similar to the values for most of the other strains tested in this study. The ant(6) gene, associated with streptomycin resistance in enterococci (del Campo et al., 2000), was demonstrated in $2 \mathrm{Lb}$. bulgaricus strains and 2 Strep. thermophilus strains, which showed streptomycin MIC in the range of 64 to $512 \mu \mathrm{g} / \mathrm{mL}$. The presence of aph $\left(3^{\prime}\right)$-IIIa or ant(6) genes seems not to be correlated with higher kanamycin or streptomycin MIC values. To our knowledge, the aph(3')-IIIa and ant(6) genes were detected in strains of $L b$. bulgaricus and Strep. thermophilus for the first time.

Other resistance genes $[\operatorname{tet}(\mathrm{K}), \operatorname{tet}(\mathrm{L}), \operatorname{tet}(\mathrm{O}), \operatorname{tet}(\mathrm{S})$, $\operatorname{tet}(\mathrm{W}), \operatorname{str}(\mathrm{A}), \operatorname{str}(\mathrm{B}), \operatorname{cat}(\mathrm{A})$, and $\left.\operatorname{aac}\left(6^{\prime}\right)-\operatorname{aph}\left(2^{\prime \prime}\right)\right]$ were not found in any of the resistant strains. This is probably due to, first, these strains possibly being intrinsically resistant to the antibiotics tested. Some resistant strains could inactivate the antibiotic by destroying or modifying the drug itself so that it is no longer toxic. Some others may pump the drug out of the bacterial cell so that the concentration of the drug is too low to be effective. Second, the emergence of resistance in these organisms may have arrived through evolutionary events, such as mutations. Some resistant species may have an altered form of the target site of the drug (the place on the cell where the drug binds), so the antibiotic cannot find its target. Third, these resistance genes were located on the chromosome but were not incomplete to be detected. Other mechanisms of antibiotic resistance should also be considered; the resistance to some antibiotics may be mediated by transposon or plasmid-carried genes.

Lactic acid bacteria strains have acquired the generally regarded as safe status and are used as fermenting lactic starter cultures in the food industry. When they are used as probiotics and enter into our intestines in large numbers, interaction with the natural intestinal microbiota and gene transfer may occur (Rojo-Bezares et al., 2006). Because LAB can be prone to gene exchange to enhance survival in antibiotic-containing environments (Toomey et al., 2009a,b, 2010), further studies are required to analyze in detail whether the genes identified in our study might be horizontally transferred to other species. In the meantime, a series of measures inspired to a principle of precaution should be undertaken, the most important of which is to systematically test strains for the presence of transferable antibiotic resistance genes before they are used as commercial starters or probiotic cultures in food products. Also, this measure should be complemented by a more prudent use of antibiotics in all fields, including agriculture, veterinary, and human medicine.

\section{CONCLUSIONS}

A variety of antibiotic resistant LAB strains was recovered from Chinese yogurt isolates. Potentially transferable resistance determinants such as tet $(\mathrm{M})$, $\operatorname{ant}(6)$, and $\operatorname{aph}\left(3^{\prime}\right)$-IIIa, were found in these isolates, fuelling the debate about the use of these bacteria in food and their potential to spread resistance through the food chain, especially in cases where the transfer of resistance has been demonstrated. Future studies should be focused on horizontal gene transfer of detected resistance genes.

\section{REFERENCES}

Aarestrup, F. M., Y. Agerso, P. Gerner-Smidt, M. Madsen, and L. B. Jensen. 2000. Comparison of antimicrobial resistance phenotypes and resistance genes in Enterococcus faecalis and Enterococcus faecium from humans in the community, broilers, and pigs in Denmark. Diagn. Microbiol. Infect. Dis. 37:127-137.

Adolfsson, O., S. N. Meydani, and R. M. Russell. 2004. Yogurt and gut function. Am. J. Clin. Nutr. 80:245-256. 
Aminov, R. I., N. Garrigues-Jeanjean, and R. I. Mackie. 2001. Molecular ecology of tetracycline resistance: Development and validation of primers for detection of tetracycline resistance genes encoding ribosomal protection proteins. Appl. Environ. Microbiol. 67:2232 .

Ammor, M. S., A. B. Flórez, and B. Mayo. 2007. Antibiotic resistance in non-enterococcal lactic acid bacteria and bifidobacteria. Food Microbiol. 24:559-570.

Amor, K. B., E. E. Vaughan, and W. M. de Vos. 2007. Advanced molecular tools for the identification of lactic acid bacteria. J. Nutr. 137:741S-747S

Amsterdam, D. 2005. Susceptibility testing of antimicrobials in liquid media. Pages 52-111 in Antibiotics in Laboratory Medicine. Vol. 4. V. Lorian, ed. Lippincott Williams \& Wilkins, Baltimore, MD.

Andrews, J. M. 2001. Determination of minimum inhibitory concentrations. J. Antimicrob. Chemother. 48:5-16.

Andrighetto, C., F. Borney, A. Barmaz, B. Stefanon, and A. Lombardi. 2002. Genetic diversity of Streptococcus thermophilus strains isolated from Italian traditional cheeses. Int. Dairy J. 12:141-144.

Belletti, N., M. Gatti, B. Bottari, E. Neviani, G. Tabanelli, and F. Gardini. 2009. Antibiotic resistance of lactobacilli isolated from two Italian hard cheeses. J. Food Prot. 72:2162-2169.

Charteris, W. P., P. M. Kelly, L. Morelli, and J. K. Collins. 1998 Antibiotic susceptibility of potentially probiotic Bifidobacterium isolates from the human gastrointestinal tract. Lett. Appl. Microbiol. 26:333-337.

CLSI (Clinical and Laboratory Standards Institute). 2009. Methods for dilution antimicrobial susceptibility tests for bacteria that grow aerobically; CLSI document M07-A8. CLSI, Wayne, PA.

Cocconcelli, P. S., D. Porro, S. Galandini, and L. Senini. 1995. Development of RAPD protocol for typing of strains of lactic acid bacteria and enterococci. Lett. Appl. Microbiol. 21:376-379.

D'Aimmo, M. R., M. Modesto, and B. Biavati. 2007. Antibiotic resistance of lactic acid bacteria and Bifidobacterium spp. isolated from dairy and pharmaceutical products. Int. J. Food Microbiol. 115:35-42.

Danielsen, M., and A. Wind. 2003. Susceptibility of Lactobacillus spp. to antimicrobial agents. Int. J. Food Microbiol. 82:1-11.

Daud Khaled, A. K., B. A. Neilan, A. Henriksson, and P. L. Conway. 1997. Identification and phylogenetic analysis of Lactobacillus using multiplex RAPD-PCR. FEMS Microbiol. Lett. 153:191-197.

de Candia, S., M. De Angelis, E. Dunlea, F. Minervini, P. L. H. McSweeney, M. Faccia, and M. Gobbetti. 2007. Molecular identification and typing of natural whey starter cultures and microbiological and compositional properties of related traditional Mozzarella cheeses. Int. J. Food Microbiol. 119:182-191.

del Campo, R., C. Tenorio, C. Rubio, J. Castillo, C. Torres, and R. Gómez-Lus. 2000. Aminoglycoside-modifying enzymes in highlevel streptomycin and gentamicin resistant Enterococcus spp. in Spain. Int. J. Antimicrob. Agents 15:221-226.

Delgado, S., A. B. Flórez, and B. Mayo. 2005. Antibiotic susceptibility of Lactobacillus and Bifidobacterium species from the human gastrointestinal tract. Curr. Microbiol. 50:202-207.

EC (European Commission). 2001. Opinion of the Scientific Committee on Animal Nutrition on the criteria for assessing the safety of micro-organisms resistant to antibiotics of human clinical and veterinary importance. Accessed Jan. 24, 2003. http://ec.europa. $\mathrm{eu} /$ food/fs/sc/scan/out108_en.pdf

EFSA (European Food Safety Authority). 2008. Update of the criteria used in the assessment of bacterial resistance to antibiotics of human and veterinary importance. EFSA J. 732:1-15.

Egervärn, M., M. Danielsen, S. Roos, H. Lindmark, and S. Lindgren. 2007. Antibiotic susceptibility profiles of Lactobacillus reuteri and Lactobacillus fermentum. J. Food Prot. 70:412-418.

Elkins, C. A., and L. B. Mullis. 2004. Bile-mediated aminoglycoside sensitivity in Lactobacillus species likely results from increased membrane permeability attributable to cholic acid. Appl. Environ. Microbiol. 70:7200-7209.

Flórez, A. B., S. Delgado, and B. Mayo. 2005. Antimicrobial susceptibility of lactic acid bacteria isolated from a cheese environment. Can. J. Microbiol. 51:51-58.
Gevers, D., M. Danielsen, G. Huys, and J. Swings. 2003. Molecular characterization of tet $(\mathrm{M})$ genes in Lactobacillus isolates from different types of fermented dry sausage. Appl. Environ. Microbiol. 69:1270-1275.

Gousia, P., V. Economou, H. Sakkas, S. Leveidiotou, and C. Papadopoulou. 2011. Antimicrobial resistance of major foodborne pathogens from major meat products. Foodborne Pathog. Dis. 8:27-38.

Irkin, R., and U. V. Eren. 2008. A research about viable Lactobacillus bulgaricus and Streptococcus thermophilus numbers in the market yoghurts. World J. Dairy \& Food Sci. 3:25-28.

Johansson, M. L., M. Quednau, G. Molin, and S. Ahrne. 1995. Randomly amplified polymorphic DNA (RAPD) for rapid typing of Lactobacillus plantarum strains. Lett. Appl. Microbiol. 21:155159.

Katla, A. K., H. Kruse, G. Johnsen, and H. Herikstad. 2001. Antimicrobial susceptibility of starter culture bacteria used in Norwegian dairy products. Int. J. Food Microbiol. 67:147-152.

Klare, I., C. Konstabel, G. Werner, G. Huys, V. Vankerckhoven, G. Kahlmeter, B. Hildebrandt, S. Müller-Bertling, W. Witte, and $\mathrm{H}$ Goossens. 2007. Antimicrobial susceptibilities of Lactobacillus, Pediococcus and Lactococcus human isolates and cultures intended for probiotic or nutritional use. J. Antimicrob. Chemother. 59:900-912

Kobayashi, N., M. Alam, Y. Nishimoto, S. Urasawa, N. Uehara, and N Watanabe. 2001. Distribution of aminoglycoside resistance genes in recent clinical isolates of Enterococcus faecalis, Enterococcus faecium and Enterococcus avium. Epidemiol. Infect. 126:197-204.

Liu, C., Z.-Y. Zhang, K. Dong, J.-P. Yuan, and X.-K. Guo. 2009. Antibiotic resistance of probiotic strains of lactic acid bacteria isolated from marketed foods and drugs. Biomed. Environ. Sci. $22: 401-412$

Lourens-Hattingh, A., and B. C. Viljoen. 2001. Yogurt as probiotic carrier food. Int. Dairy J. 11:1-17.

Mathur, S., and R. Singh. 2005. Antibiotic resistance in food lactic acid bacteria-A review. Int. J. Food Microbiol. 105:281-295.

Moore, E., A. Arnscheidt, A. Krüger, C. Strömpl, and M. Mau. 2004 Simplified protocols for the preparation of genomic DNA from bacterial cultures. Pages 3-18 in Molecular Microbial Ecology Manual. 2nd ed. G. A. Kowalchuk, F. J. de Bruijn, I. M. Head, A. D. L. Akkermans, and J. D. van Elsas, ed. Kluwer Academic Publishers, Dordrecht, the Netherlands.

Nawaz, M., J. A. Wang, A. P. Zhou, C. Ma, X. Wu, J. E. Moore, B. C Millar, and J. Xu. 2011. Characterization and transfer of antibiotic resistance in lactic acid bacteria from fermented food products. Curr. Microbiol. 62:1081-1089.

Ng, L. K., I. Martin, M. Alfa, and M. Mulvey. 2001. Multiplex PCR for the detection of tetracycline resistant genes. Mol. Cell. Probes 15:209-215

Ouoba, L. I. I., V. Lei, and L. B. Jensen. 2008. Resistance of potential probiotic lactic acid bacteria and bifidobacteria of African and European origin to antimicrobials: Determination and transferability of the resistance genes to other bacteria. Int. J. Food Microbiol. $121: 217-224$.

Rahimi. E., M. Ameri, and H. R. Kazemeini. 2010. Prevalence and antimicrobial resistance of Campylobacter species isolated from raw camel, beef, lamb, and goat meat in Iran. Foodborne Pathog. Dis. $7: 443-447$

Rojo-Bezares, B., Y. Sáenz, P. Poeta, M. Zarazaga, F. Ruiz-Larrea, and C. Torres. 2006. Assessment of antibiotic susceptibility within lactic acid bacteria strains isolated from wine. Int. J. Food Microbiol. 111:234-240.

Salyers, A. A., A. Gupta, and Y. Wang. 2004. Human intestinal bacteria as reservoirs for antibiotic resistance genes. Trends Microbiol. $12: 412-416$

Samaržija, D., S. Sikora, S. Redžepović, N. Antunac, and J. Havranek 2002. Application of RAPD analysis for identification of Lactococcus lactis subsp. cremoris strains isolated from artisanal cultures. Microbiol. Res. 157:13-17.

Teuber, M. 2001. Veterinary use and antibiotic resistance. Curr. Opin. Microbiol. 4:493-499. 
Teuber, M., L. Meile, and F. Schwarz. 1999. Acquired antibiotic resistance in lactic acid bacteria from food. Antonie Van Leeuwenhoek 76:115-137.

Teuber, M., and V. Perreten. 2000. Role of milk and meat products as vehicles for antibiotic-resistant bacteria. Acta Vet. Scand. Suppl. 93:75-87.

Toomey, N., D. Bolton, and S. Fanning. 2010. Characterisation and transferability of antibiotic resistance genes from lactic acid bacteria isolated from Irish pork and beef abattoirs. Res. Microbiol. $161: 127-135$

Toomey, N., A. Monaghan, S. Fanning, and D. Bolton. 2009a. Transfer of antibiotic resistance marker genes between lactic acid bacteria in model rumen and plant environments. Appl. Environ. Microbiol. 75:3146-3152.

Toomey, N., A. Monaghan, S. Fanning, and D. J. Bolton. 2009b. Assessment of antimicrobial resistance transfer between lactic acid bacteria and potential foodborne pathogens using in vitro methods and mating in a food matrix. Foodborne Pathog. Dis. 6:925-933.
Van Reenen, C. A., and L. M. T. Dicks. 1996. Evaluation of numerical analysis of random amplified polymorphic DNA (RAPD)-PCR as a method to differentiate Lactobacillus plantarum and Lactobacillus pentosus. Curr. Microbiol. 32:183-187.

Wegener, H. C. 2003. Antibiotics in animal feed and their role in resistance development. Curr. Opin. Microbiol. 6:439-445.

Yu, J., X. Du, W. Wang, J. Zhang, W. Liu, Z. Sun, T. Sun, and H. Zhang. 2011. Phenotypic and genotypic characteristics of lactic acid bacteria isolated from sour congee in Inner Mongolia of China. J. Gen. Appl. Microbiol. 57:197-206.

Zhao, S., P. F. McDermott, S. Friedman, J. Abbott, S. Ayers, A. Glenn, E. Hall-Robinson, S. K. Hubert, H. Harbottle, R. D. Walker, T. M. Chiller, and D. G. White. 2006. Antimicrobial resistance and genetic relatedness among Salmonella from retail foods of animal origin: NARMS retail meat surveillance. Foodborne Pathog. Dis. $3: 106-117$. 